\title{
Pengaruh Media Lembar Balik, Video Animasi Terhadap Pengetahuan dan Sikap Mengenai Reproduksi Seksualitas pada Siswa Sekolah Dasar di Jakarta Timur
}

\author{
*Frenta Helena Simaibang ${ }^{1)}$, Putri Azzahroh ${ }^{2)}$, Vivi Silawati ${ }^{3)}$ \\ ${ }^{1)}$ Program Studi Magister Kebidanan, Fakultas Kedokteran, Universitas Padjadjaran, Bandung \\ ${ }^{23)}$ Program Studi Sarjana Terapan Kebidanan, Fakultas Ilmu Kesehatan, Universitas Nasional, Jakarta
}

Corresponden author: frentaelenasimaibang@gmail.com

Received : 19 Maret $2021 \quad$ Accepted : 29 Maret 2021

Published: 30 Maret 2021

DOI: https://doi.org/10.37012/jik.v13i1.493

\begin{abstract}
ABSTRAK
Pendidikan reproduksi dan seksualitas di Sekolah merupakan peranan penting dalam meningkatkan pengetahuan bagi peserta didik. Namun pendidikan seks yang terimplementasi hanya pengenalan organ-organ reproduksi, bentuk pelanggaran, bahaya dan dampaknya.sehingga menyebabkan, anakanak berusaha mencari pengetahuan lain untuk memuaskan rasa ingin tahunya itu. Tujuan penelitian ini yaitu untuk mengetahui pengaruh media lembar balik dan video animasi terhadap pengetahuan dan sikap mengenai reproduksi dan seksualitas pada siswa Sekolah Dasar. Metode yang digunakan yaitu penelitian eksperimen dengan one group pre-test dan post-test design dimana rancangan ini terdiri dari satu kelompok kemudian diamati (pre-test) setelah itu diberikan intervensi dalam bentuk penyuluhan menggunakan media lembar balik dan video animasi ,kemudian diamati kembali (post-test). Hasil uji perbedaan yaitu rata-rata pengetahuan siswa sebelum diberikannya intervensi mengenai reproduksi dan seksualitas dengan menggunakan media lembar balik dan video animasi yaitu 7,72 dan rata-rata sesudah diberikan intervensi menjadi 10,64. Sedangkan rata-rata sikap siswa sebelum diberikannya intervensi mengenai reproduksi dan seksualitas dengan menggunakan media lembar balik dan video animasi yaitu 32,96 dan sesudah diberikan intervensi rata-rata menjadi 35,34. Sehingga disimpulkan ada pengaruh media lembar balik dan video animasi terhadap pengetahuan dan sikap mengenai reproduksi dan seksualitas pada siswa Sekolah Dasar.
\end{abstract}

Kata kunci: Pengetahuan, Sikap, Reproduksi, Seksualitas.

\begin{abstract}
Education and sexuality education in schools is an important role in increasing knowledge for students. However, the sex education that is implemented is only the introduction of the problematic organs, the dangers and their effects, so that the children try to find other knowledge to satisfy their curiosity. The purpose of this study was to measure the effect of flipchart media and animated videos on knowledge and attitudes about and sexuality in elementary school students. The method used was experimental research with one group pre-test post-test design where this design consisted of one group then observed (pre-test) after which intervention was given in the form of counseling using flipcharts and animated videos, then re-observed (post-test). The result of the difference test was that the average knowledge of the students before giving intervention regarding and sexuality using flipcharts and animated videos was 7.72 and the average after intervention was 10.64. Meanwhile, the average attitude of the students before giving the intervention regarding and sexuality using flipcharts and video media was 32.96 and after being given the intervention the average was 35.34. So there is an effect of sheet media and animated videos on knowledge and surveys about and sexuality among elementary school students.
\end{abstract}

Keywords: Knowledge, Attitudes, Reproduction, Sexuality. 


\section{PENDAHULUAN}

Kekerasan seksual pada anak menempati posisi terbesar, yaitu 50\%-62\% dari bentuk kekerasan lainnya pada anak (Unesco, 2016). WHO mengartikan kekerasan atau pelecehan seksual yang terjadi pada anak adalah keterlibatan seorang anak dalam aktivitas seksual yang dimana anak tersbut tidak sepenuh-nya paham, karena tidak adanya penjelasan mengenai pelanggaran norma kepada anak tersebut. Kekerasan seksual pada anak adalah salah satu dari sekian masalah kesehatan reproduksi yang sedang dihadapi Indonesia. Komisi Perlindungan Anak Indonesia (KPAI) menyampaikan bahwa di awal tahun 2018, telah terjadi 117 kasus pelecehan seksual pada anak, sedangkan di tahun sebelumnya, yaitu tahun 2017, telah terjadi 393 kasus (Akbar NA, 2018).

Terjadinya pelecehan atau kekerasan seksual pada anak tidak lepas dari peran orang tua atau keluarga dan juga peran sekolah sebagai tempat anak-anak mendapatkan ilmu. Sekolah dan keluarga mempunyai tanggung jawab yang sangat besar untuk membantu anak-anak dalam proses memahami tentang kesehatan reproduksi dan seksualnya. Meskipun para guru menganggap bahwa pendidikan kesehatan reproduksi dan seksual merupakan hal penting di era jaman modern ini, tapi pada kenyataannya mereka masih menganggap pendidikan kesehatan reproduksi dan seksual adalah hal yang tabu untuk dibicarakan, terlebih kepada anak-anak. (Panjaitain, RL. 2017).

Pendidikan kesehatan reproduksi dan seksual pada usia dini meliputi pengenalan organ reproduksi dan cara-cara menjaga kebersihan organ reproduksi tersebut. Dampak pemberian pendidikan kesehatan reproduksi dan seksual akan utuh bila diintegrasikan dengan orang tua, sehingga anak mempunyai pemahaman yang baik dan tidak salah mengartikannya.(Kursistin, P. 2016). Orang tua mempunyai peran yang sangat penting dalam tumbuh kembang anaknya (Widoyo R, 2015), sehingga membangun komunikasi antara orang tua dan anak perlu dilakukan dalam memperkenalkan organ reproduksi anak, fungsi dan cara merawatnya (Ahmad DN, 2017).

Beberapa faktor yang dapat berpengaruh terhadap perilaku seksual dan program pendidikan seksual antara lain, nilai-nilai yang berlaku di dalam keluarga, hubungan orang tua dan karena masih kurangnya informasi dan pengetahuan tentang seks baik dari orangtua maupun guru disekolah. 


\section{METODE}

Desain Penelitian ini adalah eksperiment dengan one group pretest-posttest dimana rancangan ini terdiri dari satu kelompok lalu diamati (pre-test) setelah itu diberikan intervensi dalam bentuk penyuluhan menggunakan media lembar balik dan video animasi, kemudian diamati kembali (post-test). Sampel dalam penelitian ini yaitu siswa/i kelas V di SDN Dukuh 01 Pagi Jakarta Timur sebanyak 50 orang dan penelitian ini dilakukan pada bulan Februari 2020.

\section{HASIL DAN PEMBAHASAN}

\section{Hasil}

Pada penelitian ini terdapat variabel pengetahuan dan Sikap siswa sebelum dan sesudah diberikan pendidikan Kesehatan tentang Pengaruh Penggunaan Media Lembar Balik dan Video Animasi Terhadap Pengetahuan dan Sikap Mengenai Reproduksi dan Seksualitas pada Siswa Sekolah Dasar. Seluruh data yang telah diperoleh kemudian dilakukan proses input data dan analisa data menggunakan program analisis data hingga mendapatkan hasil, kemudian didapatkan distribusi frekuensi sebelum dan sesudah diberikan pendidikan menggunakan media lembar balik dan video animasi di SD Negeri 01 Dukuh dengan jumlah responden 50 siswa.

\section{Analisis Univariat}

Tabel 1.

Distribusi Rata-rata Pengetahuan Siswa Sebelum dan Sesudah Diberikan Pendidikan Kesehatan Reproduksi dan Seksualitas Pada Siswa Sekolah Dasar

\begin{tabular}{|c|c|c|c|c|c|c|c|}
\hline Pengetahuan & Mean & Median & Modus & $\mathbf{n}$ & Min & Max & $\begin{array}{c}\text { Std. } \\
\text { Deviation }\end{array}$ \\
\hline Pre-Test & 7.72 & 7 & 7 & \multirow{2}{*}{50} & 3 & 13 & 2.382 \\
\hline Post-Test & 10.64 & 11 & 11 & & 5 & 15 & 2.164 \\
\hline
\end{tabular}

Berdasarkan tabel 1 di atas dapat dijelaskan bahwa sebelum dilakukan pendidikan kesehatan Reproduksi dan Seksualitas rata-rata pengetahuan siswa yaitu 7.72. Sedangkan sesudah dilakukan pendidikan kesehatan tentang kesehatan Reproduksi dan Seksualitas rata-rata pengetahuan siswa menjadi 10,64. Sehingga dikatakan terjadi perubahan sebelum dan sesudah diberikannya pendidikan. 
Tabel 2.

Distribusi Rata-rata Sikap Siswa Sebelum dan Sesudah Diberikan Pendidikan Kesehatan Reproduksi dan Seksualitas Pada Siswa Sekolah Dasar

\begin{tabular}{lccccccc}
\hline \multicolumn{1}{c}{ Sikap } & Mean & Median & Modus & n & Min & Max & $\begin{array}{c}\text { Std. } \\
\text { Deviation }\end{array}$ \\
\hline Pre-Test & 32,96 & 32,50 & 31 & \multirow{2}{*}{50} & 26 & 40 & 3,410 \\
\hline Post-Test & 35,34 & 36,00 & 37 & & 40 & 40 & 3,173 \\
\hline
\end{tabular}

Berdasarkan tabel 2 di atas dapat dijelaskan bahwa sebelum dilakukan pendidikan kesehatan Reproduksi dan Seksualitas rata-rata nilai Sikap siswa yaitu 32,96. Sedangkan sesudah dilakukan pendidikan kesehatan tentang kesehatan Reproduksi dan Seksualitas rata-rata nilai sikap siswa menjadi 36.00. Sehingga dikatakan terjadi perubahan sebelum dan sesudah diberikannya pendidikan.

\section{Analisis Bivariat}

Tabel 3.

Pengaruh Media Lembar Balik dan Video Animasi Terhadap Pengetahuan Mengenai Reproduksi dan Seksualitas Pada Siswa Sekolah Dasar

\begin{tabular}{ccccccc}
\hline Variabel & Pengukuran & n & Mean & SD & SE & \multirow{2}{*}{ P-value } \\
\hline \multirow{2}{*}{ Pengetahuan } & Pre-Test & \multirow{2}{*}{50} & 7,72 & 2.382 & 337 & \multirow{2}{*}{0,000} \\
\cline { 2 - 2 } & Post-Test & & 10,64 & 2.164 & 306 & \multirow{2}{*}{} \\
\hline
\end{tabular}

Dari tabel 3 menunjukkan hasil uji perbedaan dua kali pengukuran (Paired T-Test) yang menunjukkan bahwa sebelum dilakukan intervensi pendidikan tentang kesehatan Reproduksi dan Seksualitas, rata-rata pengetahuan siswa sebelum diberikannya intervensi pendidikan tentang kesehatan reproduksi dan seksualitas pada siswa yaitu sebesar 7,72 (st.Deviasi 2.382) dan setelah diberikannya intervensi pendidikan tentang kesehatan reproduksi dan seksualitas pada siswa rata-rata pengetahuan siswa meningkat menjadi 10.64 (st. Deviasi 2.164) dengan $P$-Value sebesar $0,000<0,05$. Sehingga dapat disimpulkan terdapat pengaruh Media Lembar Balik dan Video Sebelum dan Sesudah diberikannya pendidikan tentang kesehatan reproduksi dan seksualitas pada siswa terhadap pengetahuan siswa.

Tabel 4.

Pengaruh Media Lembar Balik dan Video Animasi Terhadap Sikap Mengenai Reproduksi dan Seksualitas Pada Siswa

\begin{tabular}{ccccccc}
\hline Variabel & Pengukuran & n & Mean & SD & SE & P-value \\
\hline \multirow{2}{*}{ Sikap } & Pre-Test & \multirow{2}{*}{50} & 32.96 & 3.410 & 482 & \multirow{2}{*}{0,000} \\
\cline { 2 - 2 } & Post-Test & & 35.34 & 3.173 & 449 & \\
\hline
\end{tabular}

Dari tabel 4 menunjukkan hasil uji perbedaan dua kali pengukuran (Paired T-Test) yang menunjukkan bahwa sebelum dilakukan intervensi pendidikan tentang kesehatan reproduksi 
dan seksualitas pada siswa rata-rata nilai sikap siswa 32,96 (st.Deviasi 3.410) dan setelah diberikan intervensi pendidikan tentang kesehatan reproduksi dan seksualitas pada siswa ratarata nilai sikap siswa meningkat menjadi 35.34 (st. Deviasi 3.173) dengan P-Value sebesar $0,0001<$ a 0,05. Sehingga dapat disimpulkan terdapat pengaruh Media Lembar Balik Sebelum dan sesudah diberikannya pendidikan tentang kesehatan reproduksi dan seksualitas pada siswa terhadap perubah sikap siswa.

\section{Pembahasan}

\section{Distribusi Rata-rata Pengetahuan Siswa Sebelum Dan Sesudah Diberikan Pendidikan}

\section{Kesehatan Reproduksi dan Seksualitas Pada Siswa}

Berdasarkan hasil pengolahan data dan sesuai dengan tujuan khusus dalam penelitian ini yaitu untuk mengetahui pengetahuan siswa sebelum dan sesudah diberikannya informasi mengenai reproduksi dan seksualitas, diperolah hasil nilai rata-rata (mean) pengetahuan sebelum diberikannya pendidikan kesehatan reproduksi dan seksualitas (pretest) sebesar 7,72 dengan Standar Deviasi 2,382 dan sesudah diberikannya intervensi kesehatan reproduksi dan seksualitas (posttest) rata-rata pengetahuan meningkat menjadi 10,62 dengan Standar Deviasi 2,164 .

Pengetahuan adalah hasil dari tahu dimana proses tahu terjadi setelah orang melakukan penginderaan terhadap suatu objek tertentu. Penginderaan terjadi melalui panca indera manusia yaitu: indera penglihatan, pendengaran, penciuman, rasa dan raba. Sebagian besar pengetahuan manusia diperoleh melalui mata dan telinga (Notoadmojo, 2010). Selanjutnya, peningkatan pengetahuan ditunjukkan melalui teori dari Purnama Jaka (2013) yang dikutip dari hasil penelitian Nurhamsyah (2015) yang menjelaskan bahwa keterlibatan indera pendengaran dan adanya tindakan dari peserta dapat menaikkan tingkat pengetahuan sebesar 90\% (Nurhamsyah, Mendri \& Wahyuningsih, 2017).

Penelitian Fatmawati (2013), tentang pendidikan kesehatan menggunakan media lembar balik pada pekerja terhadap pengetahuan $\mathrm{K} 3$, didapatkan hasil bahwa terjadi peningkatan pengetahuan pada kelompok yang diberi pendidikan dengan lembar balik. Nilai rata-rata sebelum pendidikan kesehatan yaitu 11, sedangkan setelah diberikan pendidikan kesehatan menggunakan media lembar balik nilai rata-rata pengetahuan meningkat menjadi 14 . Oleh karena itu, disimpulkan bahwa media lembar balik dan video animasi dapat mempengaruhi pengetahuan seseorang akan sesuatu hal tertentu dikarenakan media lembar balik dan video animasi ditampilkan sesuai dengan informasi dan kebutuhan yang ingin dituju. 


\section{Distribusi Rata-rata Sikap Siswa Sebelum dan Sesudah Diberikan Pendidikan} Kesehatan Reproduksi dan Seksualitas Pada Siswa

Berdasarkan hasil pengolahan data dan sesuai dengan tujuan khusus dalam penelitian ini yaitu untuk mengetahui gambaran sikap siswa sebelum dan sesudah diberikannya informasi mengenai reproduksi dan seksualitas diperolah hasil nilai rata-rata (mean) sikap sebelum diberikannya pendidikan kesehatan reproduksi dan seksualitas (pretest) sebesar 32,96 dengan Standar Deviasi 3,410 dan sesudah diberikan pendidikan kesehatan reproduksi dan seksualitas (posttest) 35,34 dengan Standar Deviasi 3,173. Terlihat perbedaan nilai mean antara sebelum dan sesudah pendidikan adalah 2,38.

Sikap merupakan respons atau perilaku tertutup seseorang terhadap stimulus yang ada, yang sudah melibatkan faktor pendapat atau emosi seseorang (senang-tidak senang, setuju-tidak setuju, baik-tidak baik, dan sebagainya). Teori Green berpendapat bahwa sikap merupakan faktor predisposisi yang mempengaruhi perilaku seseorang. Sikap adalah tanggapan batin terhadap rangsangan yang telah diterima dari luar yang menghendaki respon individual sehingga timbul perasaan suka atau tidak suka. Sikap juga dapat diartikan sebagai reaksi atau respon yang masih tertutup dari seseorang terhadap suatu stimulus atau objek.

Berdasarkan hasil Penelitian Nur Asnah Sitohang (2019) analisis kuesioner dengan menggunakan media edukasi seperti poster, video, lembar balik, leaflet dan modul memperoleh nilai rata-rata sikap siswa sebelum diberikan pendidikan kesehatan adalah 10.23 dan setelah diberikan pendidian kesehatan adalah 11.86. Hasil uji statistik diperoleh beda mean 1.62. sehingga dapat disimpulkan ada perbedaan sebelum dan sesudah diberikannya pendidikan kesehatan Reproduksi dan Seksualitas terhadap siswa.

\section{Pengaruh Media Lembar Balik Dan Video Animasi Terhadap Pengetahuan dan Sikap Siswa Mengenai Reproduksi Dan Seksualitas Pada Siswa Sekolah Dasar}

Dari tabel 3 hasil uji perbedaan dua kali pengukuran (Paired T-Test) menunjukkan bahwa sebelum dilakukan pendidikan kesehatan reproduksi dan seksualitas pada siswa rata-rata pengetahuan siswa 7,72 (st.Deviasi 2.382) dan setelah diberikan pendidikan kesehatan reproduksi dan seksualitas pada siswa rata-rata pengetahuan sisiwa menjadi 10.64 (st. Deviasi 2.164). Dari hasil analisis Paired T-Test menunjukkan $P$ Value sebesar $0,000<0,05$, maka dapat disimpulkan bahwa terdapat pengaruh media lembar balik dan video animasi terhadap pengetahuan mengenai reproduksi dan seksualitas pada siswa Sekolah Dasar.

Selanjutnya, tabel 4 hasil uji perbedaan dua kali pengukuran (Paired T-Test) menunjukkan 
bahwa sebelum dilakukan pendidikan kesehatan reproduksi dan seksualitas pada siswa diperolah hasil nilai rata- rata (mean) sikap sebelum diberikannya pendidikan kesehatan reproduksi dan seksualitas (pretest) sebesar 32,96 dengan Standar Deviasi 3,410 dan sesudah diberikan pendidikan kesehatan reproduksi dan seksualitas (posttest) sebesar 35,34 dengan Standar Deviasi 3,173. Dari hasil analisis Paired T-Test menunjukkan $P$ Value sebesar 0,000 $<0,05$ maka dapat disimpulkan terdapat pengaruh Media Lembar Balik dan video animasi terhadap sikap siswa mengenai reproduksi dan seksualitas.

Lembar balik adalah media penyampaian pesan atau informasi kesehatan. Biasanya didalam setiap lembaran buku berisi gambar peragaan dan dibaliknya terdapat kalimat yang berisi pesan-pesan dan informasi yang berkaitan dengan gambar tersebut dan Film atau video merupakan media yang dapat menyajikan pesan bersifat fakta maupun fiktif yang dapat bersifat informatif, edukatif maupun instruksional (Fitriani, 2011).

Pada penelitian Zubaidi Bajuri (2016) rata-rata perubahan pengetahuan responden kelompok pre-test sebelum penyuluhan adalah - 0.04 sedangkan pada kelompok post-test 3.20. Hasil uji statistik diperoleh nilai probabilitas sebesar 0.000 , artinya pada alpha $5 \%$ terdapat perbedaan rata-rata perubahan skor pengetahuan responden sebelum dan setelah penyuluhan antara kedua kelompok sehingga dapat dikatakan bahwa ada pengaruh yang signifikan dari penyuluhan menggunakan media lembar balik terhadap perubahan pengetahuan bahaya K3 dan pencegahannya pada pekerja bengkel las di Ciputat Kelurahan Pisangan Tahun 2014.

Sejalan dengan hasil pretest dan posttest dari kegiatan Pengabdian kepada Masyarakat, dimana terdapat perbedaan yang signifikan terhadap rata-rata pengetahuan siswa antara sebelum dan sesudah intervensi menggunakan media lembar balik. Sebelum diberikannya intervensi, rata-rata nilai siswa yaitu 9,02 dengan nilai terendah adalah 4 dan nilai tertinggi adalah 12. Sedangkan setelah diberikannya intervensi, rata-rata nilai meningkat menjadi 10,49 dengan nilai terendah yaitu 5 dan nilai tertinggi adalah 14 dengan nilai p-value atau sig 0.001. (Djaali, Wijayanti, Widodo, \& Simaibang, 2019).

Selain itu, penelitian ini juga sejalan dengan penelitian Saban (2017) tentang pendidikan penggunaan video dibandingkan dengan media leaflet pada siswi SMAN 2 Ngaglik Sleman, media video audiovisual lebih efektif dalam meningkatkan pengetahuan kesehatan dibandingkan menggunakan media flip chart. Subjek penelitian yang diberikan pendidikan kesehatan menggunakan video akan lebih mudah memahami informasi karena mengaktifkan lebih banyak indra dibandingkan hanya menggunakan flipchart. Informasi dengan video ini akan menambah pemahaman ibu sehingga pengetahuan ibu dapat lebih baik. 
Berdasarkan hasil penelitian, disimpulkan bahwa media lembar balik dan video animasi dapat mempengaruhi pengetahuan seseorang akan sesuatu hal tertentu dikarenakan media lembar balik dan video animasi ditampilkan sesuai dengan informasi dan kebutuhan yang ingin dituju. Lembar balik merupakan media dimana peneliti memperlihatkan gambar kepada peserta sambil membaca tulisan yang terletak di halaman belakang gambar. Ukuran lembar balik yang cukup besar dengan gambar, tulisan, dan komposisi warna yang tepat pada lembar balik membuat proses pendidikan atau belajar menjadi lebih mudah dan lebih menarik bagi siswa.

Kemudian media video merupakan media yang memberikan tampilan gambar bergerak yang berbentuk dari sekumpulan gambar yang disusun secara beraturan mengikuti alur pergerakan yang telah ditentukan pada setiap pertambahan hitungan waktu yang terjadi. Selajutynya, video juga merupakan suatu medium yang sangat efektif untuk membantu proses pembelajaran, baik untuk pembelajaran masal, individual, maupun berkelompok. Selain itu, ukuran tampilan video sangat fleksibel dan dapat diatur sesuai dengan kebutuhan, yaitu dengan cara mengatur jarak antara layar dan pemutar.

Dengan demikian, sejatinya media lembar balik dan video dapat dingunakan untuk secara luas dan spesifik. Kedua media tersebut mampu serta menumbuhkembangkan pengetahuan dari seseorang. Selain itu, kedua media tersebut memberikan perubahan dari tahu menjadi lebih tahu serta berpengaruh pada sikap orang tersebut. Akhirnya, media lembar dan video mampu memberikan pengetahuan serta merubah sikap pada seseorang secara spesifik dalam penelitian ini terhadap kesehatan reproduksi dan seksualitas.

\section{SIMPULAN DAN REKOMENDASI}

Dari hasil analisis Paired T-Test menunjukkan $P$ Value sebesar 0,000<0,05 maka dapat disimpulkan terdapat pengaruh media lembar balik dan video animasi terhadap pengetahuan dan sikap mengenai reproduksi dan seksualitas pada siswa SD. Diharapkan hasil dari penelitian ini dapat menambah pengetahuan dan perubahan sikap siswa mengenai kesehatan reproduksi dan seksualitas sehingga siswa dan juga media lembar balik dan video animasi dapat menjadi salah satu metode pilihan pada saat melakukan penyuluhan

\section{REFERENSI}

1. Akbar NA. Sepanjang Tahun 2018, Ada 100 lebih Korban Kekerasan Seksual terhadap Anak di Indonesia. tribunjakarta.com. 2018.

2. Panjaitan RL, Djuanda D, Hanifah N. Persepsi Guru mengenai Sex Education di 
Sekolah Dasar kelas VI. Mimb Sekol Dasar. 2017;2 (2):224-33.

3. Kursistin P. Studi Deskriptif Mengenai Pendidikan Seks Pada Anak Usia Dini Dari Perspektif Pendidik PAUD. INSIGHT. 2016;12(2).

4. Ahmad DN. Membangun Komunikasi dan Pendidikan Berkarakter dalam Keluarga dalam Pengenalan Awal Organ Seksual pada Anak. Bioedukasi J Pendidik Biol. 2017;8(2):125-33.

5. Notoatmodjo, Soekidjo. 2007. Promosi Kesehatan dan Ilmu Perilaku. Jakarta: PT Rineka cipta.

6. Nurhamsyah, D., Mendri, N. K., \& Wahyuningsih, M. (2017). Pengaruh Edukasi Terhadap Perubahan Pengetahuan dan Sikap Mahasiswa Tentang TRIAD Kesehatan Reproduksi Remaja (KRR) di Fakultas Ilmu Sosial dan Ekonomi Universitas Respati Yogyakarta. Jurnal Keperawatan Respati Yogyakarta, 2(2).

7. Fatmawati, H. (2013). Perubahan Pengetahuan tentang Potensi Bahaya Larutan Penggumpal dan Pencegahan Dermatitis dengan Intervensi Penyuluhan antara Media Lembar Balik dengan Media Leaflet pada Pekerja Pabrik Tahu di Kecamatan Ciputat dan Ciputat Timur Tahun 2013.

8. Sitohang, N. A., \& Adella, C. A. (2020). Pengaruh Pendidikan Kesehatan Terhadap Pengetahuan dan Sikap Siswa SMP Dharma Pancasila Tentang Manajemen Kesehatan Menstruasi. Jurnal Riset Hesti Medan Akper Kesdam I/BB Medan, 4(2), 126-130.

9. Fitriani, Shinta .2011, Promosi Kesehatan, Yogyakarta : Salemba Medika.

10. Bajuri, Z. Intervensi penyuluhan menggunakan media lembar balik terhadap peningkatan pengetahuan tentang bahaya Keselamatan dan Kesehatan Kerja (K3) dan pencegahannya pada pekerja las di Ciputat Kelurahan Pisangan Tahun 2014 (Bachelor's thesis, FKIK UIN Jakarta).

11. Djaali, N. A., Wijayanti, W., Widodo, Y. B., \& Simaibang, F. H. (2019). Pembentukan Duta Cilik Anti Pelecehan Seksual Melalui Pendidikan Reproduksi Dini Di SDN Bambu Apus 01 Jakarta Timur. Jurnal Pemberdayaan Komunitas MH Thamrin, 1(2), 76-86.

12. Saban, S., \& Utami, F. S. (2017). Efektifitas Media video dan leaflet Terhadap Pengetahuan Tentang Anemia Siswi SMAN 2 Ngaglik Sleman (Doctoral dissertation, Universitas' Aisyiyah Yogyakarta). 